\author{
JoAnNA MiKoŁAJCZYK ${ }^{1}$
}

\title{
Współczesne funkcje obszarów wiejskich na tle koncepcji multifunkcjonalnego rolnictwa
}

1. Rozważania dotyczące problematyki współczesnych funkcji obszarów wiejskich na tle koncepcji multifunkcjonalnego rolnictwa należy poprzedzić kilkoma uwagami natury ogólnej.

Po pierwsze, istotną przyczyną wpływającą na ocenę wartości poznawczej i naukowej przydatności twierdzeń o współczesnych funkcjach obszarów wiejskich jest wieloznaczność samego terminu ,funkcja”. ${ }^{2}$ Wieloznaczność ta jest przy tym właściwa nie tylko specjalistycznym dyskursom (np.: socjologicznemu, biologicznemu), lecz również językowi potocznemu. W języku potocznym termin „funkcja” występuje $\mathrm{w}$ wielu znaczeniach, w których przypisuje się mu bardzo różne treści. ${ }^{3}$ Okoliczność ta powoduje swoisty zamęt terminologiczny. Zasygnalizowanych kłopotów znaczeniowych nie można zatem usunąć poprzez proste odwołanie się do języka potocznego. Dotyczy to w szczególności dyskursu prawniczego, w którym silne jest, ze względu na znaczenie wykładni językowej, przyzwyczajenie do definiowania pojęć $\mathrm{z}$ uwzględnieniem postulatu zgodności z językiem potocznym. ${ }^{4}$

Po drugie, od kontrowersji nie jest wolne także pojęcie obszaru wiejskiego, które aktualnie znajduje zastosowanie w wielu zróżnicowanych kontekstach znaczeniowych. W polu badawczym tego pojęcia krzyżują się płaszczyzny oscylujące wokół problemów interesujących przedstawicieli nauki reprezentujących różne specjalizacje. Każda z tych nauk definiuje to pojęcie w autonomiczny sposób i poddaje je badaniom przy wykorzystaniu reprezentatywnych dla niej instrumentów i metod badawczych. Stąd też, w ramach eklektycznego pojęcia obszaru wiejskiego, porusza

\section{Uniwersytet Łódzki.}

2 Por.: I. Bogucka, Funkcje prawa. Analiza pojęcia, Kraków 2000. W swoich rozważaniach autorka analizuje m.in. pojęcie funkcji jako: relacji, działania (roli), celu i jako skutku. W języku potocznym wskazuje się na następujące konteksty znaczeniowe pojęcia funkcji: 1) funkcją czegoś
jest przeznaczenie, zastosowanie lub działanie tego, podporządkowanie jakimś zadaniom lub celom; 2) czyjaś funkcja to stanowisko tej osoby lub obowiązki, które ona spełnia; 3) jeśli jakieś urządzenie ma jakąś funkcję, to ma taką możliwość działania; 4) jeśli coś jest funkcją czegoś, to jest od tego pod pewnym względem zależne; 5) w matematyce funkcja to jednoznaczne przyporządkowanie elementów jednego zbioru elementom drugiego zbioru. Cytuję za: Słownik języka polskiego, t. 1, M. Bańko (red.), Warszawa 2007, s. 526. 
się problematykę wykorzystania i zagrożenia obszarów wiejskich, zagospodarowania przestrzennego obszarów wiejskich; mówi się o rozwoju obszarów wiejskich, globalizacji i jej wpływie na obszary wiejskie, czy wreszcie o kulturze i odnowie obszarów wiejskich. Nie można nie zauważyć, że coraz więcej dyscyplin naukowych przedmiotem swoich zainteresowań czyni właśnie zagadnienie obszarów wiejskich - nie jest to problem tylko prawnej natury.

Po trzecie, zasygnalizowana wyżej wieloznaczność tych podstawowych z punktu widzenia tematu opracowania - terminów, stała się źródłem rozbieżności poglądów doktrynalnych na kwestię istoty i charakteru obszaru wiejskiego, a także swoistego katalogu przypisywanych mu aktualnie funkcji. Okoliczność ta znalazła odzwierciedlenie w literaturze przedmiotu, zwłaszcza w doktrynie niemieckiej. Przekonanie o randze i doniosłości badań o charakterze uniwersalnym pozwala stwierdzić, iż dalsze rozważania będą stanowiły próbę uporządkowania tychże poglądów, a ponadto już w założeniu mają doprowadzić do uzyskania odpowiedzi na następujące pytania: czy w dobie „przewidywania” perspektyw rozwoju wspólnej polityki rolnej po 2013 roku dostrzega się potrzebę dookreślenia pojęcia obszaru wiejskiego; czy uwspółcześniona definicja obszaru wiejskiego stanowi odpowiedź na wielofunkcyjność rolnictwa i wreszcie, czy wyrażane w doktrynie zachodnioeuropejskiej zapatrywania w tym względzie dają podstawę do sformułowania swoistego katalogu współczesnych funkcji obszarów wiejskich.

2. Przystępując do rozważań zmierzających do sformułowania odpowiedzi na pierwsze ze wskazanych wyżej pytań, przywołajmy na wstępie dylematy dotyczące zmiany siatki pojęciowej nauki prawa rolnego. Jak trafnie odnotowano już w literaturze, aktualnie jesteśmy świadkami pewnego fenomenu, który zdaniem J. Martíneza, sprowadza się do zjawiska fali reform terminologicznych. Autor dosadnie konstatuje, że „gdy brakuje pomysłów, reformuje się pojęcia”. ${ }^{5} \mathrm{~W}$ centrum zmian terminologicznych umiejscawia się pojęcie obszaru wiejskiego. Równocześnie wskazuje się na wiele różnorodnych przyczyn rewizji „,szaty pojęciowej” nauki prawa rolnego, a ściślej rzecz biorąc „tradycyjnych pojęć” wspólnej polityki rolnej. Jak się wydaje, ilość zmian w otoczeniu i ich waga są na tyle istotne, by stanowić przesłankę modyfikacji także celów nadrzędnych wspólnej polityki rolnej. ${ }^{6} \mathrm{~W}$ literaturze do najbardziej popularnych propozycji nowego ujęcia tychże celów zalicza się: zapewnienie bezpieczeństwa żywnościowego, mitygację i adaptację do zmian klimatycznych, zwiększenie konkurencyjności europejskiego sektora rolnego, ochronę środowiska na obszarach wiejskich, a przede wszystkim zachowanie różnorodności gląd Prawa Rolnego" 2010, nr 2, s. 47. temat: A. Jurcewicz, (w:) Traktat ustanawiający Wspólnotę Europejską. Komentarz, t. 1, A. Wróbel (red.), Warszawa 2008 , s. 723-746. 
biologicznej, bardziej skuteczną gospodarkę zasobami wodnymi czy rozwój produkcji energii odnawialnej.7 Zdefiniowanie właściwych celów o charakterze strategicznym jest o tyle ważne, że determinuje sposób ich realizacji, a zatem wybór właściwego instrumentarium. Ogólne cele wspólnej polityki rolnej powinny znaleźć swoje przełożenie w działaniach operacyjnych. Działania operacyjne powinny być z kolei właściwie pogrupowane, tak aby tworzyć logiczną, spójną i przejrzystą ,architekturę systemu". W tym kontekście na znaczeniu zyskuje problem zmian semantycznych w odniesieniu do pojęcia obszaru wiejskiego.

2.1. Ujmując zagadnienie w nieco szerszej perspektywie historycznej, przypomnijmy, że początków terminu „obszar wiejski” upatrywać należy w polityce. Na płaszczyźnie europejskiej pierwsze wyraźne symptomy pojawienia się tego pojęcia zauważyć można w działaniach Rady Europy, która w latach 1987-88 przeprowadziła szeroko zakrojoną kampanię, a jej zalecenia stały się jednocześnie wytycznymi dla wielu działań podejmowanych na gruncie polityk państwowych i ponadpaństwowych. Efektem zainicjowanych przez Radę Europy posunięć było przyjęcie na posiedzeniu parlamentarnym Rady w dniu 23 kwietnia 1996 r. sprawozdania o Europejskiej Karcie Obszarów Wiejskich. ${ }^{8}$ Sprecyzowane w niej założenia zmierzały do nowego metodycznego podejścia i wprowadzenia określonych instrumentów do polityki w odniesieniu do obszarów wiejskich. We wspomnianej Karcie Rada Europy określiła obszar wiejski jako samodzielną przestrzeń życiową, która powinna być pielęgnowana i rozwijana $\mathrm{z}$ uwzględnieniem uwarunkowań poszczególnych terenów, przy czym działania te powinny mieć charakter całościowy. ${ }^{9}$

Na początku lat 90 -tych $\mathrm{XX}$ wieku ${ }^{10}$ problematyka rozwoju obszarów wiejskich pojawiła się także w działaniach Organizacji Współpracy Gospodarczej i Rozwoju (OECD). W dalszej kolejności syntetycznie choćby wskazać należy na - szeroko już skomentowane w literaturze ${ }^{11}$ - działania i reformy Wspólnej Polityki Rolnej podejmowane przez Unię Europejską, począwszy od 1999 r., które znalazły swój formalny wyraz w dokumencie Agenda $2000 .{ }^{12}$ Wskazano w nim, że należy wypracować wszechstronnie przemyślaną politykę rozwoju terenów wiejskich, która ma stanowić jedną z polityk Unii Europejskiej. Reforma ta, odwołując się do europejskiego modelu rolnictwa, podkreślała m.in.: znaczenie polityki rozwoju obszarów wiejskich i polityki ochrony środowiska w ramach wspólnej polityki rolnej, a także

7 W. Chmielewska-Gill, A. Chlebicka, A. Poślednik, Przyszłość WPR - najważniejsze głosy w dotychczasowej dyskusji, Warszawa 2010, s. 3.

8 Zalecenie nr 1296/1996; zob.: Wnioski Prezydencji Rady Europejskiej. Luksemburg, 12-13 grudnia 1997 r.

9 H.P. Jeschke, Die Europäische Charta für den ländlichen Raum und neue Strategien für die ländlich geprägten Räume Österreichs, http://www.berggebiete.at/cms/content/view/183/244/

10 Welche Zukunft für unsere ländlichen Räume? Eine Politik der ländlichen Entwicklung, Paris, OECD 1993.

11 Por. np.: A. Jurcewicz, P. Popardowski, J. Zięba, Ewolucja wspólnej polityki rolnej, (w:) Prawo i polityka rolna Unii Europejskiej, A. Jurcewicz (red.), Warszawa 2010, s. 31-52.

12 Por. np.: Agenda 2000. Unia Europejska rozszerzona i silniejsza, „Monitor Integracji Europejskiej” 1999, wyd. specj. 
zwiększenie bezpieczeństwa i jakości produktów rolnych. Nie sposób tu szerzej rozwijać zagadnienia ewolucji wspólnej polityki rolnej, gdyż zbyt daleko odwróciłoby to naszą uwagę od głównego wątku rozważań, a mianowicie współczesnej koncepcji obszaru wiejskiego. Generalnie można stwierdzić, że w swoim rozwoju wspólna polityka rolna konsekwentnie ewoluuje w kierunku polityki rozwoju obszarów wiejskich. Rolnictwo europejskie ma bowiem charakter wielofunkcyjny, a jego prawidłowy rozwój powinien uwzględniać również problematykę ochrony środowiska naturalnego, rozwoju obszarów wiejskich, bezpieczeństwa i jakości produktów rolnych oraz zróżnicowania działalności rolniczej. ${ }^{13}$ Przedmiotem zaś zainteresowania polityki rozwoju obszarów wiejskich nie jest więc wyłącznie rolnictwo sensu stricte. W zdecydowanie większym stopniu akcentowana jest problematyka wzmocnienia tych obszarów w zakresie m.in. stworzenia nowych rodzajów usług oferowanych przez rolników, odnowy i rozwoju wsi, ochrony i utrzymania dziedzictwa kulturowego. ${ }^{14}$ Stąd też kierowane do szeroko pojmowanych obszarów wiejskich działania obejmujące przykładowo politykę rolną, programy zatrudnienia, działania w zakresie polityki energetycznej i ochrony środowiska, programy infrastrukturalne, wsparcie grup lokalnych czy programy wspierające turystykę pozwalają na stwierdzenie, że działania te mają charakter wielowymiarowy, by nie rzec kompleksowy.

2.2. Zastanawiając się zatem nad potrzebą i zasadnością rewizji terminologicznej w odniesieniu do pojęcia obszaru wiejskiego, należy jednocześnie zwrócić szczególną uwagę na kwestię niezbędnej ostrożności w zakresie (re)definiowania pojęć tak podstawowych jak pojęcie obszaru wiejskiego. Wiele nadużyć polega bowiem na „naginaniu pojęć dla doraźnych celów polityki bieżącej”. ${ }^{15}$ Odwołując się do poglądu Z. Duniewskiej warto skonstatować, że uwarunkowania polityczne są niebagatelnym czynnikiem kształtowania prawa. Co więcej, niektórzy autorzy wręcz uznają możliwość traktowania prawa jako podsystemu systemu politycznego, w którym normy polityczne występują obok, ale też niejako wewnątrz unormowań prawnych. ${ }^{16}$ Zapatrywanie to zdaje się potwierdzać trwająca obecnie dyskusja polityczna dotycząca kształtu wspólnej polityki rolnej po 2013 roku, w tym dwóch jej istotnych elementów: dopłat bezpośrednich oraz wsparcia rozwoju obszarów wiejskich. Debata ta o zabarwieniu politycznym, zdaniem J. Martíneza, ,wykorzystuje koncepcję obszaru wiejskiego głównie w celu uwzględnienia idei wielofunkcyjno-

Szerzej na ten temat: E. Tomkiewicz, Tendencje rozwojowe współczesnego prawa rolnego, „Studia Prawnicze” 2001, z. 3-4, s. 337-350.

O potrzebie rewitalizacji przestrzeni niematerialnej wsi (związanej z powrotem do indywidualnych kulturowych cech wsi, jej zwyczajów i historii) a także rewitalizacji jej przestrzeni materialnej (dotyczącej programów odnowy wsi, przywracania i eksponowania tradycyjnej zabudowy) - por.: S. Kamosiński, Rewitalizacja przestrzeni niematerialnej i materialnej wsi. Kształtowanie wizerunku obszarów wiejskich, „Samorząd Terytorialny” 2011, nr 9, s. $5-16$. w nauce prawa administracyjnego. Księga jubileuszowa dedykowana Profesorowi Janowi Bociowi, Wrocław 2009, s. 126. 
ści rolnictwa, koncepcji, która w ostatnich latach z mocą utorowała sobie drogę, wykorzystywanej najpierw w sferze politycznej, a następnie naukowej”. ${ }^{17}$ A przecież, jak trafnie wskazuje I. Lipowicz, dorabianie ex post uzasadnienia dla polityki stanowi krańcowy upadek nauki. ${ }^{18}$

Kwestia modyfikacji zastanych, tradycyjnych pojęć nie jest wyłącznie problemem naszej legislacji prawnorolnej. Dostrzega go również doktryna innych krajów europejskich, w tym zwłaszcza doktryna niemiecka. I tak, np. R. Norer broni szerokiego ujęcia obszaru wiejskiego i proponuje zastąpienie koncepcji rolnictwa koncepcją obszaru wiejskiego. ${ }^{19}$ Oceny nowych propozycji i reakcje na nie są zróżnicowane. Ogólnie jednak przyjmuje się, że największą burzę pojęciową w krajowych doktrynach powoduje integracja europejska. Okoliczność ta została wnikliwe wyjaśniona i zdiagnozowana w doktrynie niemieckiej..$^{20}$ Odwołując się do poglądu S. Baer, który wprawdzie został wyrażony przez autorkę w związku z problematyką nauki prawa administracyjnego, niemniej jednak pozostaje aktualny w poruszanej tu kwestii nauki prawa rolnego, ${ }^{21}$ zauważmy, że można wyróżnić trzy fazy typowej reakcji doktryny wobec głębokich społecznych przemian, niedających się ująć za pomocą dotychczas stosowanych pojęć. Faza pierwsza oscyluje wokół opisywania i pojmowania zasadniczych przemian społecznych, takich jak: zjawisko planowania czy techniczne i społeczne ryzyko. Na taki nowy społeczny fenomen nauka reaguje swoistym otwarciem metod pracy - ,rozgląda się w naukach sąsiednich, patrzy jak inne dyscypliny radzą sobie z tym fenomenem i próbuje wyciągnąć wnioski dla nauk prawnych”. W drugiej fazie spostrzegamy rozszerzającą się ,niepewność teoretyczną" oraz wielość proponowanych rozwiązań. W fazie trzeciej zaś możemy mówić o konsolidacji nauki prawa. Po wypracowaniu wystarczających strategii radzenia sobie z opisywanym fenomenem nauka prawa powraca do dogmatycznych, charakterystycznych dla niej metod pracy i próbuje ponownie „odgrodzić się” od tych dyscyplin naukowych, które nie korzystają z metod dogmatycznych. ${ }^{22}$

Odnosząc te uwagi do analizowanego zagadnienia, można chyba stwierdzić, że aktualnie znajdujemy się w fazie drugiej, w której cechą charakterystyczną jest swoisty chaos terminologiczny. W fazie tej panuje jeszcze niejasność co do zakresu znaczeniowego poszczególnych pojęć, ich istoty, charakteru, rozróżnień, podziałów czy klasyfikacji. Pewny jest tylko polityczny wydźwięk zmian semantycznych.

17 J. Martínez, Pojęcie „obszar wiejski”..., op. cit., s. 49.

18 I. Lipowicz, Dylematy zmiany siatki pojęciowej w nauce prawa administracyjnego, (w:) Koncepcja systemu prawa administracyjnego, J. Zimmermann (red.), Warszawa 2007, s. 21.

19 R. Norer, Skizzen aus der agrarrechtlichen Zukunft: ein Recht des ländlichen Raums? (1) „Agrar- und Umweltrecht" 2008, nr 5, s. 160.

20 S. Baer, Schlüsselbegriffe, Typen und Leitbilder als Erkenntnismittel und ihr Verhältnis zur Rechtsdogmatik, (w:) Methoden der Verwaltungsrechtswissenschaft, E. Schmid-Asmann, W. Hoffmann-Riem, (red.) Baden-Baden 2004, s. 223-252.

21 Szerzej na temat relacji prawa rolnego z innymi dziedzinami prawa: R. Budzinowski, Problemy ogólne prawa rolnego. Przemiany podstaw legislacyjnych i koncepcji doktrynalnych, Poznań 2008, s. 203-224. Cytuję za: I. Lipowicz, Dylematy zmiany siatki pojęciowej..., op. cit., s. 27-28. 
Jak podkreśla J. Martínez, pojęcie obszaru wiejskiego jawi się przede wszystkim jako instrument przezwyciężania trzech wyzwań stojących przed europejskim prawem rolnym w związku z zachowaniem jego tradycyjnych struktur: 1) umiędzynarodowienia prawa rolnego w Światowej Organizacji Handlu, 2) jego demokratyzacji w Unii Europejskiej z Parlamentem odpowiedzialnym za wspólną politykę rolną, 3) przezwyciężenia tradycyjnych struktur prawnych i gospodarczych polityki rolnej. ${ }^{23}$

Odnotowane okoliczności powodują konieczność sprecyzowania znaczenia terminu „obszar wiejski” także w języku prawnym. Definiowanie pojęć ma bowiem ogromne znaczenie w każdym systemie, a zwłaszcza w takim, który odwołuje się do pojęć abstrakcyjnych.

2.3. Truizmem jest twierdzenie, że współcześnie pojęcie obszaru wiejskiego wydaje się być po prostu „modne”. W związku z wielopłaszczyznowym podejściem do pojęcia obszaru wiejskiego pojawia się kwestia (re)definiowania czy raczej „uwspółcześnienia” tego pojęcia. W nauce prawa rolnego definicji takich jest bardzo wiele - spektakularnym przykładem może tu być doktryna prawa niemieckiego. ${ }^{24}$ Jako przykład definicji negatywnej w literaturze niemieckiej podaje się następującą propozycję: ,przez obszar wiejski rozumie się niezurbanizowane terytorium powierzchni Ziemi lub część jednostki samorządu terytorialnego, która nie jest sklasyfikowana jako obszar miejski lub będący efektem ekspansji miasta". ${ }^{25}$

Nie ulega jednak wątpliwości, że pojęcie obszaru wiejskiego nie może być postrzegane jedynie przez pryzmat rolnictwa, choć jest ono z nim związane, bowiem związek ten nie ma charakteru nierozerwalnego. Wobec cały czas widocznego, dość silnie zarysowanego podziału na linii miasto - wieś w poszczególnych definicjach dają się wyróżnić pewne wspólne punkty ich odniesienia, takie jak mała gęstość zaludnienia ${ }^{26}$ wysoki udział w ogólnej liczbie społeczeństwa ludności utrzymującej się z rolnictwa oraz - statystycznie rzecz ujmując - posiadanie przez mieszkańców tych obszarów stosunkowo dużej powierzchni ziemi wykorzystywanej na cele mieszkalne lub wypoczynkowe. W zakresie struktury wiekowej ludności wiejskiej podnieść należy przede wszystkim kwestię dużego udziału ludzi starszych i starych. Ponadto widoczne są określone deficyty na płaszczyźnie infrastruktury. Z drugiej jednak strony z łatwością można dostrzec obszary, które znakomicie się rozwijają. Doskonałą ilustracją w tym względzie są turystyczne regiony górskie. Współczesny obraz obszarów wiejskich nie jest więc jednolity. ${ }^{27}$

Zob. M. Dombert, Ch. Grimm, Zum Begriff des ländlichen Raumes: Tagungsbericht und Ausblick zu einer rechtspolitischen Diskussion, „Agrar-und Umweltrecht” 2007, nr 7, s. 225.

C. Lienau, Die Siedlungen des ländlichen Raums, Braunschweig 1995, s. 15.

Por. R. Pastuszko, Rozwój obszarów wiejskich, (w:) Prawo rolne, A. Oleszko (red.), Warszawa 2009, s. 261.

R. Norer, Skizzen aus der agrarrechtlichen Zukunft: ein Recht des ländlichen Raums?..., op. cit., s. 159. 
3. Analizując problem rewaloryzacji prawnej wielofunkcyjności działalności rolniczej, J. Martínez stwierdził, że „puntem wyjścia koncepcji obszaru wiejskiego nie jest zatem perspektywa funkcjonalna, ograniczająca się do rolnika i jego przedsiębiorstwa, lecz perspektywa obejmująca zewnętrzne skutki jego działalności i oddziaływanie na nią otoczenia, a także wszelkie rodzaje działalności gospodarczej, które są zgrupowane w ramach pojęcia różnicowania działalności rolniczej”. ${ }^{28}$ Przyjrzyjmy się koncepcji rolnictwa multifunkcjonalnego, także tej wypracowanej przez przedstawicieli doktryny niemieckiej, z perspektywy ,zakotwiczenia” w niej tych elementów, które pozwalają na „rewaloryzację prawną” obszaru wiejskiego, a w dalszej kolejności stanowią podstawę wskazania jego współczesnych funkcji.

3.1. W naukach ekonomicznych podkreślono, że w przeciwieństwie do wielofunkcyjności wsi, która od wielu lat jest obecna i dyskutowana w literaturze, wielofunkcyjność rolnictwa jako zjawisko społeczno-ekonomiczne, a zarazem kategoria analityczna jest zagadnieniem mało rozpoznanym i niedostatecznie uwzględnianym w badaniach. Postulując przeprowadzenie wszechstronnej analizy wielofunkcyjności rolnictwa tak w naukach społecznych, jak i przyrodniczych, J. Wilkin wskazywał, że koncepcja ta (jakkolwiek stanowiąca hasło wykorzystywane na użytek dialogu politycznego) wiąże się silnie ze zrównoważonym rozwojem rolnictwa i obszarów wiejskich oraz nowym podejściem do analizy gospodarowania w krajach wysoko rozwiniętych, nazwanym postproduktywizmem. ${ }^{29} \mathrm{~W}$ swoich rozważaniach autor sformułował następujące tezy: 1) wielofunkcyjność rolnictwa jest niezbędnym warunkiem zrównoważonego rozwoju kraju, 2) wiele funkcji realizowanych przez rolnictwo jest słabo rozpoznanych, skwantyfikowanych i opisanych, 3) pozakomercyjne funkcje rolnictwa stają się podstawą legitymizacji i głównym celem publicznego wsparcia dla rolnictwa, 4) zjawisko nierozłączności, a więc powiązanie pozytywnych efektów zewnętrznych rolnictwa z produkcją dóbr rynkowych, uniemożliwia wyłączenie elementów protekcjonizmu z polityki rolnej. ${ }^{30}$ Równocześnie autor zwrócił uwagę na zasadniczą trudność dotyczącą identyfikacji szerokiej gamy nierynkowych efektów rolnictwa, dotyczących zarówno sfery gospodarczej, społecznej, kulturowej, jak i przyrodniczej. ${ }^{31}$

Akcentując ponownie, odnotowaną już na wstępie rozważań, doniosłość badań o charakterze uniwersalnym, zwłaszcza z uwagi na możliwość dokonania pewnego wartościowania poprzez wskazanie, które z rozwiązań wypracowanych w doktrynie zachodnioeuropejskiej zasługują na szczególne zainteresowanie polskiego usta-

28 J. Martínez, Pojęcie „obszar wiejski”..., op. cit., s. 49. Tak też: C. Grimm, Agrarrecht, München 2004, s. 12.

29 J. Wilkin, Wielofunkcyjność rolnictwa i obszarów wiejskich, (w:) Wyzwania przed obszarami wiejskimi i rolnictwem w perspektywie lat 2014-2020, M. Kłodziński (red.), Warszawa 2008, s. 12.

30 Ibidem, s. 12-13.

31 J. Wilkin, Ewolucja społeczno-ekonomicznych podstaw legitymizacji Wspólnej Polityki Rolnej Unii Europejskiej, (w:) Polska wieś i rolnictwo w Unii Europejskiej. Dylematy i kierunki przemian, M. Drygas, A. Rosner (red.), Warszawa 2008, s. 39. 
wodawcy, przyjrzyjmy się bliżej zwłaszcza germańskiej koncepcji rolnictwa multifunkcjonalnego.

3.2. W doktrynie prawa niemieckiego wskazuje się, że pojęcie „,rolnictwo multifunkcjonalne" może zostać skonkretyzowane na dwa sposoby: poprzez definicję albo przez utworzenie grup funkcyjnych wraz z wymienieniem przykładów.

Gdy chodzi o ujęcie definicyjne, za przykład posłużyć może definicja robocza studium OECD, w świetle której ,,multifunkcjonalność dotyczy istnienia rozmaitych towarów i nietowarowych dóbr i usług, które współprodukowane są przez rolnictwo". ${ }^{32}$ Nieco bardziej konkretnie można by zdefiniować rolnictwo multifunkcjonalne w tym sensie, że ,rolnictwo wykonuje świadczenia ważne społecznie i pożądane, które nie wyrażają się w ocenie monetarnej produkowanych zbiorów, zatem nie mogą być ujęte w ogólnym rachunku ekonomicznym". ${ }^{33}$ Jak podkreśla P. Käb, dla obu definicji wspólny jest problem pozytywnego zdefiniowania czegoś, co w rezultacie stanowi sumę oddziaływań negatywnych na wypadek, gdyby rolnictwo wycofało się w znacznym stopniu $\mathrm{z}$ danego rejonu. Tym samym definicje te są o tyle problematyczne, że nie pozwalają ostatecznie rozeznać, jakie funkcje przypadają rolnictwu ${ }^{34}$ Stąd też dla określenia pojęcia "rolnictwo multifunkcjonalne" bardziej celowe zdaje się być zastosowanie grup funkcyjnych.

W doktrynie niemieckiej przyjęło się zasadniczo dzielenie funkcji rolnictwa na grupy funkcyjne, przy czym proponowane delimitacje charakteryzuje zabarwienie subiektywne - grupy funkcyjne różnią się między sobą w zależności od preferencji poszczególnych autorów. ${ }^{35}$ Ciekawe rozróżnienie w ramach grup funkcyjnych, będące jednocześnie „wspólnym mianownikiem” proponowanych w niemieckiej literaturze ujęć tego zagadnienia, zaproponował P. Käb. Autor ten wyróżnił następujące grupy funkcyjne rolnictwa multifunkcjonalnego:

\section{funkcja produkcyjna:}

- żywność i pasze,

- surowce,

- nośniki energii;

Por.: Multifunktionalität: Auf dem Weg zu einem analytischen Rahmen, OECD 2001, s. 9; także: A. Heißenhuber, H. Hoffmann, Honorierung einer multifunktionalen Landwirtschaft, „Ländlicher Raum” 2002, nr 5, s. 1(3). W. Pevetz, Konzept und Begründung multifunktionaler Landwirtschaft, 1999, (w:) H.K. Wytrzens (red.), Effizienz und Wettbewerbsfähigkeit in der Agrarpolitik, Kiel, s. 135-147. M. Penker, S. Pfusterschmid (red.), Dokumentation der 11. ÖGA-Jahrestagung an der Karl-Franzens-Universität Graz, 27. und 28. September 2001, Wien, 2003, s. 245; 248 i nast.; R. Norer, Lebendiges Agrarrecht, Wien 2005, s. 488. 


\section{funkcja usługowa:}

- osobista relacja wytwórca - konsument np. sprzedaż bezpośrednia,

- urlop w gospodarstwie rolnym,

- usługi komunalne, np.: pielęgnacja terenów zielonych, kompostowanie,

- pomoc w razie klęsk żywiołowych,

- opieka nad ludźmi starymi w związkach rodzinnych,

- regionalna samowystarczalność energetyczna dzięki odnawialnej energii z biopaliw, energii słonecznej i wiatrowej,

- przeróbka odpadów i recykling;

\section{funkcja ekonomiczna i lokalna:}

- miejsca pracy i źródło dochodu,

- różnorodność w regionalnej gospodarce/regionalna wartość rynkowa,

- budowa sieci różnych działań gospodarczych,

- doświadczenie i wiedza ekspercka,

- obszary dystansowe wobec emisji,

- dbałość o krajobraz poprzez zachowanie powierzchni uprawy (funkcja wolnych przestrzeni),

- przygotowanie terenów wypoczynkowych, a także uprawnych,

- utrzymanie infrastruktury,

- zaopatrzenie lokalne,

- zasiedlenie minimalne (minimalna gęstość zaludnienia),

- rezerwacja powierzchni na cele budowlane, nowe surowce przemysłowe, nośniki energii,

- rezerwacja powierzchni na okoliczność kryzysów,

- ochrona przed zagrożeniami naturalnymi,

- wysoka jakość i bezpieczeństwo żywności ,

- funkcja buforowa na rynku pracy;

\section{funkcja ekologiczna:}

- zróżnicowanie biologiczne,

- zapewnienie ekologicznej przestrzeni kompensacyjnej,

- zapewnienie wody, tworzenie wód gruntowych, dbałość o wody,

- naturalna funkcja regeneracyjna,

- ochrona klimatu, 
- kształtowanie krajobrazu i dbałość o krajobraz,

- rozmaitość gatunków biologicznych (zachowanie puli genów),

- gospodarowanie zgodne z naturą;

\section{funkcja społeczna:}

- życie wsi (stowarzyszenia, kościoły, sklepy),

- utrzymywanie tożsamości obszarów wiejskich dzięki krajobrazowi i obyczajowości,

- zachowanie lokalnej tradycji, kultury i historycznej struktury.

Odwołując się do spostrzeżeń Autora, podkreślmy, że tak jak w większości prób kategoryzacji, tak również i tutaj dochodzi do przecinania, krzyżowania i nakładania się na siebie poszczególnych funkcji.

3.3. Rozpatrując zagadnienie tworzenia ujęcia nakierowanego na funkcję w doktrynie niemieckiej dostrzeżono pewną trudność. Wskazano, że o ile wszystkie definicje pojęcia „rolnictwo” zorientowane są na czynności (tzn. zakwalifikowanie jakiegoś zachowania jako rolnictwa nawiązuje do wykonywania określonej czynności), o tyle problemy rolnoprawne pojawią się zwłaszcza tam, gdzie zachodzi wątpliwość, na ile rozumienie rolnictwa multifunkcjonalnego pokrywa się z klasycznym rozumieniem pojęcia rolnictwa. Problem ten nie może zostać rozstrzygnięty dopóty, dopóki ujęcie dla rolnictwa jest czynnościowe, zaś dla rolnictwa multifunkcjonalnego funkcjonalne. Należało zatem skorygować któreś z tych ujęć. Jako że również definicje prawne rolnictwa są zorientowane na czynności, to do rozstrzygania problemów prawa rolnego należało znaleźć ujęcie zorientowane na czynności także dla rolnictwa multifunkcjonalnego. ${ }^{36}$

Często - przynajmniej w niemieckiej literaturze prawnorolnej - czynności dające się zaliczyć do rolnictwa multifunkcjonalnego zrównywane są z tymi, które obejmuje pojęcie ,dywersyfikacji”. ${ }^{37} \mathrm{~W}$ doktrynie niemieckiej istnieje przynajmniej zgodność poglądów w tym sensie, że koncepcja multifunkcjonalności jest ściśle związana z dywersyfikacją.

$\mathrm{Z}$ tego też względu najpierw należy wyjaśnić, jakie czynności zaliczone zostały do dywersyfikacji w dziedzinie rolnictwa. Pojęcie „dywersyfikacja” obejmuje w tym kontekście możliwości łączenia zarobkowania i osiągania dochodów w rolnictwie. Można przy tym rozróżnić trzy kategorie dywersyfikacji:

- poziomą (horyzontalną), wirtschaft, „AgrarR” 2001, s. 1; idem., Auswirkungen des Strukturwandels in den ländlichen Räumen auf das Agrarrecht, „AgrarR” 2002, s. 69, 74. 
- pionową (wertykalną),

- boczną (lateralną).

Dywersyfikacja pozioma obejmuje rozszerzenie dotychczasowego programu produkcji o produkty pokrewne, takie jak produkty ekologiczne, rośliny przyprawowe i lecznicze, choinki bożonarodzeniowe.

Dywersyfikacja pionowa określa generalnie działalność poprzedzającą lub następczą wobec dotychczasowej produkcji. Zalicza się do niej zwłaszcza sprzedaż bezpośrednią w jej różnych przejawach (w gospodarstwie, na polu i na targu) i wytwarzanie produktów końcowych gotowych do konsumpcji (jak np. wędliny czy konfitury).

Dywersyfikacja boczna zawiera w sobie odgałęzienia w kierunku nowych dla przedsięwzięcia obszarów produkcyjnych bądź usługowych. Zaliczamy do nich: urlop w gospodarstwie rolnym (camping, pokoje dla letników, mieszkania i domy wakacyjne), oferty dla myśliwych czy wędkarzy, parkingi dla urlopowiczów z transferem na lotniska, pielęgnację zieleni komunalnej, ustawową ochronę przyrody, golf i jeździectwo (w tym także terapeutyczną jazdę konną), wytwarzanie energii (biomasa, woda, wiatr), gastronomię w gospodarstwie, usuwanie odpadów biologicznych, obsługę imprez, opiekę nad osobami starszymi, odśnieżanie i posypywanie dróg, tworzenie azylów dla zwierząt (np. koni, psów), chłopskie gościńce przy autostradach. $^{38}$

W praktyce jako kluczowe elementy dywersyfikacji wykrystalizowały się następujące elementy: sprzedaż bezpośrednia, wakacje w gospodarstwie (agroturystyka), pensjonaty dla zwierząt, produkcja surowców odrastających i kwestie bioenergetyczne. ${ }^{39}$

$\mathrm{W}$ dalszym ciągu bez odpowiedzi w doktrynie niemieckiej pozostaje jednak kwestia relacji między pojęciami „rolnictwo multifunkcjonalne” i „dywersyfikacja". ${ }^{40}$ Jak podkreśla P. Käb, nie wydaje się możliwe ogólnie akceptowane rozgraniczenie pojęć „dywersyfikacja” i „rolnictwo multifunkcjonalne”. Podczas gdy w ujęciu zorientowanym na funkcję dywersyfikacja stanowi szczególny przejaw rol-

P. Käb, Multifunktionale Landwirtschaft als agrarrechtliches Problem?, „Agrar-und Umweltrecht” 2003, nr 3, dodatek I, s. 3. Rozróżnienie poniższe opiera się na: Lammel: Entwicklungslinien der multifunktionalen Landwirtschaft, „AgrarR” 1995, zał. I s. 3(5); O. Seibert, Formen von Erwerbskombinationen in ländlichen Räumen, In: Erwerbskombinationen in der Landwirtschaft, Schriftenreihe des Bundesministerium für Ernährung, Landwirtschaft und Forsten, Angewandte Wissenschaften Heft 383, Landwirtschaftsverlag Münster-Hiltrup, 1990, s. 23 (27); $\mathrm{H}$. Gatterbauer, Besondere Rechtsprobleme der Landwirtschaft in Berggebieten und anderen von der Natur benachteiligten Gebieten, Diskussionspapier Nr. 27-R-94 des Instituts für Wirtschaft, Politik und Recht, Universität für Bodenkultur Wien, 1994, s. 446 (451 i nast.).

Por.: R. Norer, Lebendiges Agrarrecht, op. cit., s. 491 i nast.; A. Heißenhuber, H. Hoffmann, Honorierung einer multifunktionellen Landwirtschaft..., op. cit., s. 1(4); D. Müller, Strategien für den ländlichen Raum in Europa, Beiträge zur II. Bayerisch-Österreichischen Strategietagung 2005 / Bayerisches Staatsministerium für Landwirtschaft und Forsten, München 2005, s. 19. 
nictwa multifunkcjonalnego, to w przypadku ujęcia zorientowanego na działalność rolnictwo multifunkcjonalne jest specjalnym przejawem dywersyfikacji. ${ }^{41}$

3.4. Z puntu widzenia prowadzonych tu rozważań niezwykle istotną zdaje się być także kwestia wyznaczenia granic spektrum działalności rolnictwa multifunkcjonalnego. Problem ten wart jest bliższego rozpoznania. W doktrynie niemieckiej pytanie o to, jakie działania mieszczą się jeszcze w pojęciu rolnictwa multifunkcjonalnego, zostało sformułowane przez Ch. Grimma. ${ }^{42}$ Dla udzielenia odpowiedzi w zakresie wskazanej wątpliwości autor ten wypracował ,teorię cebuli”. Ujęcie graficzne tej teorii prezentuję poniżej.

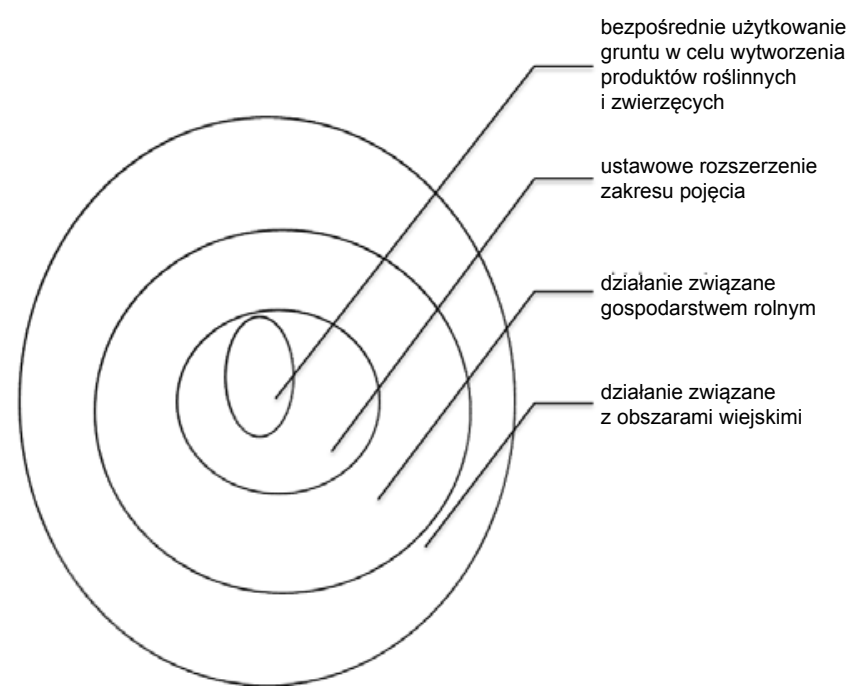

Źródto: opracowanie własne na podstawie: Ch. Grimm: Von der Landwirtschaft zur Wirtschaft auf dem Lande - Gedanken zum Begriff der Landwirtschaft?, cz. 1., „Agrarrecht” 2001, nr 1, s. 3.

Zaprezentowana powyżej „teoria cebuli” doczekała się swoistej modyfikacji, w ramach której P. Käb rozbudował pierwotną, wyjściową wersję, wskazując na dodatkowy, najbardziej zewnętrzny jej krąg. Stąd też autor wyróżnił pięć przylegających do siebie kręgów obejmujących wszystkie działalności dywersyfikujące:

1) najmniejszy i najbardziej wewnętrzny krąg obejmuje jako jądro pojęcia rolnictwa bezpośrednie wykorzystanie ziemi do wytwarzania produktów roślinnych i zwierzęcych (np. uprawa zbóż),

2) krąg drugi obejmuje rozszerzenia legislacyjne pojęcia i objaśnienia, 
3) krąg trzeci obejmuje działalność z odniesieniem do rolnictwa (np. wakacje w gospodarstwie rolnym),

4) czwarty krąg zawiera działalność z odniesieniem do terenów wiejskich (np. golf),

5) najbardziej zewnętrzny i otulający poprzednie krąg piąty obejmuje wszystkie pozostałe działalności dywersyfikujące, a więc także i te, które nie mają odniesienia do terenów wiejskich (np. opieka nad osobami starymi).

Dla potrzeb swoich rozważań P. Käb przyjął krąg trzeci za granicę tego, co można właśnie jako działalność zaliczyć jeszcze do rolnictwa multifunkcjonalnego. Granica ta określona została przez stosunek działalności do gospodarstwa rolnego (ujęcie gospodarcze). Pozostając przy tych spostrzeżeniach, autor poszukiwał kryteriów rozgraniczenia dla działalności rolnictwa multifunkcjonalnego. Przedmiotem jego szczególnego zainteresowania okazała się kwestia wyznaczenia „linii demarkacyjnej" pomiędzy kręgiem trzecim a czwartym w oparciu o relacje do gospodarstwa rolnego. ${ }^{43}$ Analizując zagadnienie kryteriów rozgraniczenia, P. Käb wskazał dwa założenia, na tle których działalność nierolnicza może jeszcze zostać zaliczona do rolnictwa multifunkcjonalnego:

1) gospodarstwo, mimo wykonywania nierolniczej działalności, odpowiada jeszcze cechom gospodarstwa rolnego $\mathrm{i}$

2) istnieje związek funkcjonalny między działalnością nierolniczą a konwencjonalnym gospodarstwem rolnym, opisanym w kręgach jeden i dwa.

Uszczegółowiając swój punkt widzenia, P. Käb podkreślał, że odwołanie się do wskazanych kryteriów rozgraniczania działalności rolnictwa multifunkcjonalnego wydaje się o tyle usprawiedliwione, że w obydwu przypadkach chodzi o konieczne zaliczenie działalności nierolniczej do rolnictwa. Odnotowane kryteria rozgraniczenia sprawdziły się także w praktyce.

Pierwsze wskazane kryterium, kryterium cech charakterystycznych, nawiązuje do gospodarstwa rolnego. Odnosi się jednakże nie tylko do istniejącej zabudowy, lecz - w pewnym stopniu - również do wykonywanej działalności. Ilustracją tej tezy jest przywołany przez autora przykład, w myśl którego „,sklepik z własnymi wyrobami w zagrodzie odpowiada jeszcze cechom gospodarstwa rolnego, zaś sklepik tak samo mały z częściami samochodowymi, już nie". ${ }^{44} \mathrm{O}$ tym, co odpowiada cechom gospodarstwa rolnego, decyduje przyjęty zwyczaj. Tak ujęte i sprecyzowane kryterium umożliwia bardziej dynamiczną wykładnię dostosowaną do zmian zachodzących w rolnictwie. 
Kryterium związku funkcjonalnego nawiązuje zaś do działalności rolniczej i spełnia przy tym podwójną funkcję. Z jednej strony wymaga podtrzymywania działalności z kręgu pierwszego bądź drugiego, co wydaje się usprawiedliwione przez fakt, że raczej nie można mówić o rolnictwie wtedy, gdy wykonywana jest działalność jedynie z kręgu trzeciego. Jeżeli na przykład były rolnik oferowałby jedynie „wakacje w gospodarstwie rolnym”, to może i mogłoby to odpowiadać cechom charakterystycznym gospodarstwa rolnego, lecz bez współistnienia zatrudnienia w rolnictwie. W sytuacji tej chodziłoby o pensjonat na wsi, a nie o agroturystykę. Z drugiej zaś strony, odnotowane kryterium związku funkcjonalnego zapewnia możliwość wykonywania działań rolniczych w sensie istnienia specyficznej relacji z działaniami również rolniczymi. W przeciwnym razie działania rolnicze same w sobie straciłyby co najmniej ich rolnicze „współnacechowanie”. Spektakularnymi przykładami ilustrującymi te spostrzeżenia są: opieka nad ludźmi starymi i terapeutyczna jazda konna. Opieka nad osobami starszymi mogłaby w zasadzie odbywać się również niezależnie od istnienia gospodarstwa rolnego, gdyż nie wykazuje żadnego szczególnego związku z działalnością rolniczą. W przeciwieństwie do tego terapeutyczna jazda konna wykazuje silną więź z rolniczą hodowlą koni.

W konkluzji tego wątku rozważań można stwierdzić, że w świetle postulatów doktryny niemieckiej działalność nierolnicza może zostać zaliczona do zakresu rolnictwa multifunkcjonalnego, jeżeli także i przy jej wykonywaniu zachowane zostaną cechy gospodarstwa rolnego i istnieje związek funkcjonalny z działalnością rolniczą.

Odnosząc się do potrzeby wyjaśnienia problemów rolnoprawnych rolnictwa multifunkcjonalnego, P. Käb postulował równocześnie dokonanie hierarchizacji analizowanych ujęć. Autor dostrzegał bowiem konieczność przedłożenia nad panujące ujęcie zorientowane na funkcję - podejście zorientowane na działalność. Ujęcie zorientowane na działalność rolnictwa multifunkcjonalnego obejmuje swoim zakresem przedmiotowym wszystkie działania ujęte pod pojęciem „,dywersyfikacji”, o ile znajdują się one w związku z gospodarstwem rolnym. ${ }^{45}$

3.5. Problem identyfikacji i klasyfikacji funkcji rolnictwa multifunkcjonalnego dostrzeżony został także w doktrynie belgijskiej. ${ }^{46}$ Sformułowano w niej propozycję klasyfikacji pozakomercyjnych funkcji rolnictwa, dzieląc je na 4 grupy:

1) funkcje zielone - zarządzanie zasobami ziemi w celu utrzymania jej wartościowych właściwości, stwarzanie warunków dla dziko żyjących zwierząt i roślin, ochrona dobrostanu zwierząt, utrzymanie bioróżnorodności i poprawa obiegu substancji chemicznych w systemach produkcji rolnej;

46 G. Van Huylenbroeck, V. Vandermeulen, E. Mettepenningen, A. Verspecht, Multifunctionality of agriculture: a review of definitions, evidence and instruments, Living Reviews in Landscape Research, 2007. Cytuję za: J. Wilkin, Wielofunkcyjność rolnictwa i..., op. cit., s. 15-16. 
2) funkcje błękitne - zarządzanie zasobami wodnymi, poprawa jakości wód, zapobieganie powodziom, wytwarzanie energii wodnej i wiatrowej;

3) funkcje żółte - utrzymanie spójności i żywotności obszarów wiejskich, podtrzymywanie i wzbogacanie tradycji kulturalnej oraz tożsamości wsi i regionów, rozwój agroturystyki i myślistwa;

4) funkcje białe - zapewnienie bezpieczeństwa żywnościowego i zdrowej żywności.

3.6. Ciekawa klasyfikacja rynkowych i pozarynkowych funkcji rolnictwa została również zaproponowana w nauce ekonomicznej. Akcentując znaczenie potrójnego zakorzenienia rolnictwa, a mianowicie zakorzenienia: terytorialnego (przestrzennego), przyrodniczego i społecznego, J. Wilkin przypisał rolnictwu następujące funkcje:

\begin{tabular}{|c|c|}
\hline 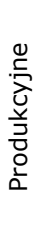 & $\begin{array}{l}\text { Komercyjne: } \\
\text { - artykuły żywnościowe przeznaczone na rynek } \\
\text { - artykuły rolne stanowiące surowce przemysłowe, w tym biomasa } \\
\text { Niekomercyjne: } \\
\text { - samozaopatrzenie gospodarstwa domowego w żywność } \\
\text { - wytworzone w gospodarstwie środki produkcji na własne potrzeby }\end{array}$ \\
\hline 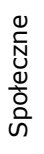 & $\begin{array}{l}\text { - wpływ na żywotność i spójność społeczną wsi } \\
\text { - element zabezpieczenia społecznego dla rodzin rolniczych } \\
\text { - stabilizator wstrząsów wywołanych zmianami gospodarczymi i instytucjonalnymi } \\
\text { (tzw. bufor szoków zewnętrznych) }\end{array}$ \\
\hline $\begin{array}{l}0 \\
\frac{0}{3} \\
0 \\
\frac{1}{3} \\
\frac{ \pm}{2}\end{array}$ & $\begin{array}{l}\text { - ochrona i wzbogacanie tradycji kulturalnych na wsi } \\
\text { - wzbogacanie kultury narodowej } \\
\text { - wzmacnianie tożsamości i różnorodności kulturowej na poziomie lokalnym, regionalnym } \\
\text { i krajowym } \\
\text { - kształtowanie kapitału kulturowego } \\
\text { - ochrona pejzażu kulturowego wsi }\end{array}$ \\
\hline 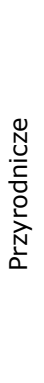 & $\begin{array}{l}\text { Negatywne: } \\
\text { - zanieczyszczanie gleby i wód środkami chemicznymi } \\
\text { - erozja gleb } \\
\text { - zmniejszanie bioróżnorodności terenów rolniczych } \\
\text { - emisja gazów cieplarnianych } \\
\text { Pozytywne: } \\
\text { - zapobieganie degradacji przyrodniczej użytków rolnych } \\
\text { - ochrona bioróżnorodności terenów rolniczych } \\
\text { - ochrona bądź poprawa stosunków wodnych na terenach rolniczych } \\
\text { - zapobieganie erozji gleb }\end{array}$ \\
\hline
\end{tabular}

Źródto opracowania: J. Wilkin, Wielofunkcyjność rolnictwa i obszarów wiejskich (w:) Wyzwania przed obszarami wiejskimi i rolnictwem w perspektywie lat 2014-2020, M. Kłodziński (red.), Warszawa 2008, s. 16. 
4. Sformułowanie konkluzji tych rozważań nie jest rzeczą prostą. Dotyczą one bowiem bardzo złożonej i wielostronnie uwarunkowanej problematyki. Jednakże podejmując próbę krótkiego podsumowania, można chyba stwierdzić, że:

- istotą nowoczesnego podejścia do rewizji pojęć prawa rolnego, w tym zwłaszcza pojęcia obszaru wiejskiego i rolnictwa multifunkcjonalnego, jest uznanie ich wyjątkowości. Nauka prawa rolnego ,dzieli je” z innymi dyscyplinami „sąsiednimi” - naukami politycznymi, socjologią, demografią czy ekonomią. Powstają eklektyczne pojęcia, w których element interdyscyplinarny jest szczególnie rozbudowany. Jednocześnie jednak sygnalizowana otwartość pojęciowa nie może prowadzić do utraty tożsamości tych pojęć, nie może także oznaczać bezkrytycznej recepcji koncepcji wypracowanych w porządkach normatywnych innych krajów;

- o ile wcześniej stałość i stabilizacja były cnotami rolników, o tyle aktualnie akcentuje się elastyczność i zdolność dopasowania się do istniejących warunków. Realizacja wskazanych wyżej dynamicznych celów skutkuje w chwili obecnej tak szerokim spektrum rodzajów działalności wykonywanej przez rolników, że powstaje wręcz problem rozgraniczenia działalności o charakterze rolniczym od tej działalności, która tego charakteru nie posiada. Coraz trudniej precyzyjnie wyznaczyć granicę, zwłaszcza w odniesieniu do rolnictwa multifunkcjonalnego;

- aktualny model rolnictwa multifunkcjonalnego, zwłaszcza ten skonstruowany w doktrynie niemieckiej, determinowany jest wieloma przesłankami, przy czym żadna z nich nie spełnia, jak sądzę, szczególnej, wiodącej roli na tle pozostałych. Wszystkie one odznaczają się już w założeniu cechą wspólną. Ich „klamrą spinającą” jest bowiem wielowymiarowy wydźwięk przejawiający się $\mathrm{w}$ zjawisku nierozłączności funkcji. Pozaprodukcyjne funkcje rolnictwa są związane z jego funkcjami produkcyjnymi. Aby skutecznie i efektywnie realizować funkcje społeczne, kulturowe, przyrodnicze, usługowe czy ekologiczne, rolnictwo musi istnieć i działać w produkcyjnej sferze swej aktywności. Warto podkreślić, że wiele pozytywnych, nieprodukcyjnych funkcji rolnictwa ma charakter uboczny, stanowiąc de facto zewnętrzny efekt działalności komercyjnej (produkcyjnej);

- obszerny katalog rozmaitych czynników wyznaczających współczesną koncepcję obszaru wiejskiego na tle rolnictwa multifunkcjonalnego daje podstawy do dokonywania ich typologii i zróżnicowanych podziałów, przyjmujących za punkt wyjścia rozmaite kryteria. Prezentowane w literaturze, a przywołane w niniejszym opracowaniu klasyfikacje współczesnych funkcji obszarów wiejskich, czy też rolnictwa multifunkcjonalnego mają w gruncie rzeczy charakter względny i oparte są na przyjętej konwencji. Nie są to jednak podziały rozłączne. Niektóre ze wskazanych funkcji implikują sie- 
bie wzajemnie. Nie jest też łatwo wyznaczyć ich hierarchię, zwłaszcza bez odniesienia się do konkretnego czasu i miejsca. Wydaje się jednak, że przemyślana współczesna koncepcja obszaru wiejskiego może być punktem wyjścia, koncepcją, wokół której będą integrować się w funkcjonalną całość interdyscyplinarne założenia rozwijające także analizowane tu zagadnienie rolnictwa multifunkcjonalnego. 


\section{MODERN FUNCTIONS OF RURAL AREAS IN THE CONCEPT OF MULTIFUNCTIONAL AGRICULTURE}

Key words: rural area, function of agriculture, common agricultural policy.

The article aims at answering the following questions: 1) Is the definition of rural area necessary, at the time of "predicted" development prospects of common agricultural policy after 2013? 2) Is a modern definition of rural area an answer to the multifunctional character of agriculture? 3) Are the considerations on this subject a good basis for the construction of a catalogue of modern rural areas? The analysis results in a conclusion that the key to a modern approach to the revision of the "conceptual design" of common agricultural policy is the acceptance of its exceptional character. New eclectic concepts arise, based on widely spread interdisciplinary elements. The open character of the concepts should not cause the loss of their identity and cannot mean any uncritical reception of concepts developed in normative systems of other countries. A modern model of multifunctional agriculture is determined by many factors, none of them being the leading element. All of them have a common feature by definition and the "buckle" is the inseparability of their functions. The non-production functions of agriculture are closely related to the production. Agriculture must exist and function in its production activity to effect its social, cultural, natural, service and environmental functions. A vast catalogue of various factors that determine a modern concept of rural area in the multifunctional agriculture forms the basis for their typology and divisions. The classifications of modern functions of rural areas, as proposed in professional literature, are relative. The divisions are not separable - some of the functions imply one another. 